\title{
EURASIAN JOURNAL OF BUSINESS AND MANAGEMENT
}

\author{
http://www.eurasianpublications.com
}

\section{The Role of Ethical Sensitivity and Self-Esteem on Academic Performance in Accounting Course}

\author{
Emine Yilmaz Karakoc
}

Çankırı Karatekin University, Turkey. Email: emine_yilmaz2004@yahoo.com

\begin{abstract}
The main objective of the current study is to investigate whether ethical sensitivity and selfesteem affect the academic performance of business students in financial accounting course. Also, the relationships among self-esteem - ethical sensitivity - cynicism were examined. The data was gathered from students in undergraduate business program of one public university in Turkey via questionnaire. Factor, reliability and regression analyses were conducted to analyze the data and to test hypotheses of the study. The results showed that ethical sensitivity and selfesteem have positive effect on academic performance. Self-esteem has positive impact on ethical sensitivity. In addition, results displayed that cynicism negatively affects the ethical sensitivity of students. It was also found that ethical sensitivity has mediation effect on the relationship between self-esteem and academic performance.
\end{abstract}

Keywords: Accounting, Academic Performance, Ethical Sensitivity, Self-esteem, Cynicism

\section{Introduction}

Interest of global business community and researchers in ethics is increasing day by day. Increasing scandals play an important role in this growing interest. Although these scandals emerged in different sectors, almost all of them are concerned with the accounting process of related companies. Waste Management, Xerox, Enron, WorldCom, Lehman Brothers, and Toshiba accounting scandals could be listed as some examples of them. Accounting scandals revealed an important issue in the business world; business ethics, especially accounting ethics. As a result, recently accounting ethics is one of the most popular subjects which accounting researchers interested in.

Chan and Leung (2006) indicated that accounting profession has some controversial characteristics in its nature related to ethics. Despite its controversial nature, behavioral ethics of accountants has crucial role in protecting prestige and credibility of accounting profession (Chan and Leung, 2006). Ethical sensitivity in accounting profession is one of the most important factors which influence business success (Fischer and Rosenzweig, 1995). In parallel with business success, it is an important indicator of the success of accountants. In order to preserve trust of public in accountants and provide more accurate and reliable information to stakeholders, ethical sensitivity of accountants and managers should be raised (Fischer and Rosenzweig, 1995). 
Because the managers and accountants of futures are educated at universities, growing ethical problems in business world increased the importance of ethics education at universities. Researchers such as Hunt and Vitell (2006) indicate that the objective of ethics education is to raise ethical sensitivity. If educational program at universities can infuse the ethical sensitivity towards accounting practices, unethical behavior related to accounting could be diminished (Fischer and Rosenzweig, 1995). So, the ethical sensitivity of university students is one of the most important predictors of future accounting professionals' ethical positions.

There are lots of studies which focus on the accounting ethics education (Loeb, 1988; Cohen and Pant, 1989; Ponemon, 1993; Geary and Sims, 1994; Kerr and Smith, 1995; Adkins and Radtke, 2004) and business ethics in general (Cole and Smith, 1995; Duizend and McCann, 1998; Gautschi and Jones, 1998; Adkins and Radtke, 2004), but there is no study which examines the relationship between ethical sensitivity of students and their academic performance in accounting course. As the academic performance of students is one of the fundamental issues of higher education, researchers have investigated the way to increase academic performance of students. As it is stated above, especially for accounting profession, ethical sensitivity is the crucial success factor. From this point of view, it is investigated in this study whether the ethical sensitivity has the same impact on academic success of the students in accounting course.

The main purpose of the current study is to examine the factors affecting academic performance of undergraduate business students in financial accounting course. For this purpose, the relationship among self-esteem, cynicism, ethical sensitivity and academic performance of students was investigated via data gathered from students in business department of one public university in Turkey.

The current study is organized as follows; the next section will provide comprehensive theoretical background. Hypotheses and research model are also developed in this section. The third section provides information about the research method. The forth section reports the analyses and results. In the last section, the results are summarized and interpreted.

\section{Theoretical Background and Hypotheses}

The main purpose of the current study is to examine the potential determinants of undergraduate business students' academic performance in financial accounting course. For this purpose, the impact of ethical sensitivity, self esteem and cynicism on academic performance and relationship among these variables are investigated.

\subsection{Academic Performance}

In literature, there are some researchers who investigate the factors affecting academic performance of students. Cohn (1972) indicates that some factors such as intelligence, maturity, motivation and background determine the academic performance of students. Also, Rankin et al. (2003), Hartnett et al. (2004) and Guney (2009) suggest that age and gender affect the performance. According to Guney (2009), teaching quality and examination structure are the other important determinants of academic success. Many researchers investigated the effect of different factors on academic performance. Self-esteem (Giovazolias et al. 2008; Akinleke, 2012; Arshad et al. 2015; Yilmaz, 2011), locus of control (Yilmaz, 2011), learning styles (Yilmaz, 2011), age, gender (Guney, 2009; Rankin et al., 2003; Hartnett et al. 2004), quality of teaching, examination structure (Guney, 2009) are a few of these factors.

The academic performance of the undergraduate students in several courses plays an important role on their carrier choice and business performance. For this reason, the determinants of academic performance of the students in financial accounting courses are investigated in the current study. 


\subsection{Ethical sensitivity}

Dellaportas et al. (2011, p.70) describe ethical sensitivity as "...the way people initially encode an ethical situation and the consequences that a person's actions might have on others". According to them (Dellaportas et al., 2011), ethical sensitivity of students is one of the essential requirements in order to be realized ethical problems by them and to increase awareness of accountants of future in order to understand possible effects of unethical accounting problems on other people. If they do not realize ethical problems, they cannot behave ethically. Raising ethical awareness and sensitivity of students prevents unethical behavior during the education period as well as during their professional carriers.

Chan and Leung (2006) didn't found significant relationship between accounting students' ethical sensitivity and their ethical reasoning. They also found that students who have internal locus of control have more capability to realize unethical issues than students who have external locus of control. Fischer and Rosenzweig (1995) conducted a study which investigates the relationship between attitudes of undergraduate students, MBA students, and practicing accountants and ethical acceptability of earnings management. Fischer and Rosenzweig (1995) found that the ethical sensitivity level of business students and practitioners is low and disparate. Because of that, they suggest some changes in educational program in order to increase ethical sensitivity.

According to Sparks and Hunt (1998), person who has less ethical sensitivity are more prone to ignore the existence of ethical issues in comparison with person who has more ethical sensitivity. Ameen et al. (1996) found that ethical sensitivity of female accounting students is higher than male students. In addition, they found that male students are more cynical and they behave more unethically than female students were. Simga-Mugan et al. (2005) also reported that nationality and gender are two factors which affect ethical sensitivity of decision makers.

Afifah et al. (2015) reported that ethical sensitivity has positive impact on auditor performance. As it is stated by Dellaportas et al. (2011), ethical sensitivity of students is quite important factor for realizing ethical problems and to increase awareness of accountants of future in order to understand possible effects of unethical accounting problems on other people. By taking into consideration the impact of ethical sensitivity on accounting profession, it can be presumed that ethical sensitivity of students also positively affect the academic performance of students as well as accountants and auditors. According to this explanation, the impact of ethical sensitivity on academic performance of future accountants and managers of future was investigated and hypothesized as follows:

Hypothesis 1: Ethical sensitivity has positive effect on the academic performance of business students in accounting course.

\subsection{Self-Esteem}

Rosenberg $(1963$, p.5) defines self-esteem as a positive or negative attitudes of individuals towards certain object or personality. Many researchers believe that if individuals have high selfesteem, they will behave more positively (Baumeister et al. 2003). On the basis of this assumption, previous studies purposed significant and positive relationship between selfesteem and academic performance (Giovazolias et al. 2008; Akinleke, 2012; Arshad et al. 2015). According to Landis et al. (2007), when the students have high self-efficiency, they can use their study skills better. Another study found that students with high self-esteem tend to appraise high self-assessment to their own performance (Jussim et al. 1987).

These findings could be criticized according to the perspective of Baumeister et al.'s (2003). According to them, the modest relationship between self-esteem and academic performance doesn't show that self-esteem positively affects academic performance and high self-esteem could be the result of high academic performance. On the other hand, some researchers indicated that there is no statistically significant relationship between self-esteem and academic success (Baumeister et al. 2003). Crocker and Luhtanen (2003) signify that low 
self-esteem of students creates social problems but not academic or financial problems for college students.

High self-esteem plays a buffer role against stress and individual with high self-esteem can cope better with stress in comparison with individual with low self-esteem (Baumeister et al. 2003). If people cope with stress, they can be more likely aware of unethical situations. On the basis of the assumption about that students with high self-esteem will behave more positively and previous research conducted by Giovazolias et al. (2008), Akinleke (2012) and Arshad et al. (2015), this study suggests that self-esteem positively affects academic performance and ethical sensitivity of students. These suggestions are hypothesized as follows;

Hypothesis 2: Self-esteem has positive effect on the academic performance of business students in accounting course. students.

Hypothesis 3: Self-esteem has positive effect on the ethical sensitivity of business

Hypothesis 4: Ethical sensitivity has the mediation effect on the relationship between self-esteem and academic performance of business students.

\subsection{Cynicism}

Cynicism is described as a tendency of individuals to criticize negatively and to be skeptical about the moral principles and values accepted by the society (Kopelman, 1983). Business students planning to be an accountant or manager as a carrier choice should internalize these moral principles and values. However, increasing accounting scandals and negative perceptions about accounting profession disillusion them about these moral principles and values and they can be cynical. Cynical students more likely disobey the moral principles and values. According to Sierles et al. (1980) and Ameen et al. (1996), it is more likely that more cynical students show more controversial and unethical behavior. From this perspective, in the current study, it is purposed that more cynical students have low ethical sensitivity. This proposition is hypothesized as follows; students.

Hypothesis 5: Cynicism has negative effect on the ethical sensitivity of business

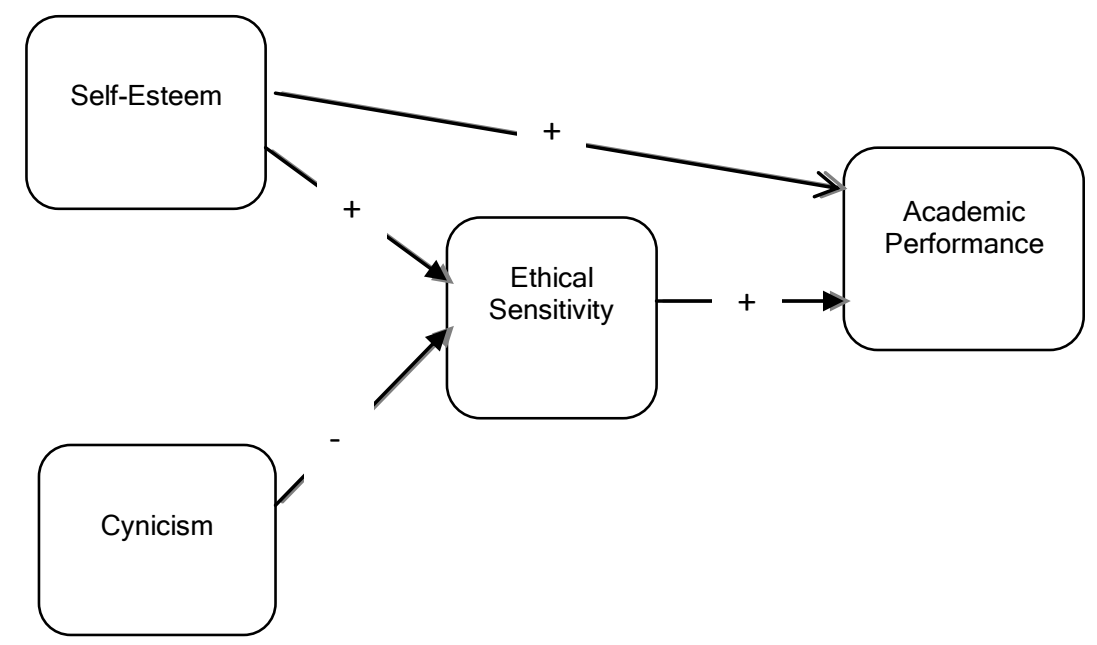

Figure 1. Research model 


\section{Method}

The variables of this study are academic performance, ethical sensitivity, self-esteem and cynicism. The reliability of the scales has been proved by previous research conducted in accounting and other fields. Factor, reliability, correlation and regression analyses are carried out to analyze data. All statistical analysis was done by using SPSS statistical package program.

\subsection{Sample and Data Collection}

In the current study, the data is gathered from the undergraduate business students of one public university in Turkey between November-October 2014 by meeting with students by face to face or using the internet. In order to collect data, the questionnaire was developed by using five-point Likert-tipe scales. 160 questionnaires were distributed to the students and 112 usable questionnaires were received. According to this, the response rate is calculated as $\% 70$. After excluding questionnaires which consist of missing cases and misleading answers of managers, the final data consist of 100 valid questionnaires with about 0.63 response rate. It shows that a good response rate was achieved for the data (Babbie, 1989, 1990).

The average age of respondents was 21.78 years old (standard deviation=1.36) and their ages are ranged from 19 to 25 years. $47 \%$ of the respondents were female and \%53 was male.

\subsection{Measurement}

The midterm score and final scores are the most important indicator of performance and success in the courses. Because of that, the academic performance was measured though average of midterm and final score of students in financial accounting course.

Ethical sensitivity scale was adapted from the study of Ameen et al. (1996). Eight questionable items were used to measure ethical sensitivity. The respondents were asked to rate severity of these items in the context of ethics. All items of scale were measured by using five-point Likert-type scale ranging among $0=$ not cheating, 1 = least, $2=$ somewhat, $3=$ moderately, 4 = quite, 5 = most. Therefore, low severity rating indicates low level of ethical sensitivity to ethical issues asked and high severity rating indicates high level of ethical sensitivity. For each items, average scores are calculated in order to analyze data. Means of the ethical sensitivity scale items are ranging from 1 to 5 .

Self-Esteem of students was measured with 5 items adapted from Rosenberg (1963). Respondents were asked to rate the statements related to their self-esteem. The items were evaluated with five point Likert-type scale with possible responses ranging from $1=$ strongly disagree and $5=$ strongly agree. High scores show high self esteem of students and low scores show low level of self-esteem.

Cynicism was measured with 3 items adapted from the study of Ameen et al. (1996). Each of the items was measured by five point Likert-type scale with possible responses ranging from 1 = strongly disagree and 5 = strongly agree.

\section{Analyses and Results 4.1. Factor, Reliability and Correlation Analyses}

As it is expected, explanatory factor analysis used to evaluate factor structure of variables pointed out three factors (Table 1). These three factors explain $63,835 \%$ of total variance. This rate is over the acceptable lower limit $(0.60)$ (Nakip, 2003). According to the Kaiser- Meyer-Olkin $(0.850)$ and Barlett test $(p=0.000)$, results of analyses are statistically significant (Mitchell, 1994) and the data is appropriate for performing factor analysis.

Scales of the current study were used and tested previously. Because of that, scales of ethical sensitivity, self-esteem and cynicism are theoretically strong. In order to confirm reliability 
of scales, the Cronbach's Alpha value was used. According to results, the reliability of the scales was satisfactory. The Cronbach's Alpha coefficients of three variables are higher than 0.60 (the acceptable lower limit; Nunnally, 1978; Malhotra, 1993) The Cronbach's Alpha coefficients of the variables are as follows; ethical sensitivity $=0.922$; self-esteem $=0.824$ and cynicism $=0.649$.

Factor loadings and reliability coefficients of variables are presented in Table 1.

Table 1. Factor loadings

\begin{tabular}{|c|c|c|c|}
\hline Factors and Scales & Factor 1 & Factor 2 & Factor 3 \\
\hline \multicolumn{4}{|l|}{ Ethical Sensitivity (Crombach $\alpha: 0.922$ ) } \\
\hline Looking at another student's exam paper during tests. & .877 & & \\
\hline Giving answers to someone else during an exam. & .876 & & \\
\hline Taking an exam for a friend. & .858 & & \\
\hline $\begin{array}{l}\text { Arranging to sit next to someone in order to copy off that } \\
\text { individual's test paper. }\end{array}$ & 840 & & \\
\hline Using unauthorized "crib" notes during an exam. & .838 & & \\
\hline Exchanging papers during an exam. & .716 & & \\
\hline Obtaining a copy of the exam prior to taking it in class. & .695 & & \\
\hline $\begin{array}{l}\text { Obtaining an old test from a student who took the class in a } \\
\text { previous semester when the professor has expressly prohibited } \\
\text { the release of old tests. }\end{array}$ & .670 & & \\
\hline \multicolumn{4}{|l|}{ Self-Esteem (Crombach $\alpha: 0.824)$} \\
\hline $\begin{array}{l}\text { I feel that I'm a person of worth, at least on an equal plane with } \\
\text { others. }\end{array}$ & & .795 & \\
\hline I take a positive attitude toward myself. & & .794 & \\
\hline I feel that I have a number of good qualities. & & .785 & \\
\hline I am able to do things as well as most other people. & & .734 & \\
\hline On the whole, I am satisfied with myself. & & .680 & \\
\hline \multicolumn{4}{|l|}{ Cynicism (Crombach $\alpha:$ 0.649) } \\
\hline Everybody steals, cheats, or lies at least once in his lifetime. & & & .754 \\
\hline People who say they have never cheated are hypocrites. & & & .743 \\
\hline People have to cheat in this "dog eat dog" world. & & & .729 \\
\hline
\end{tabular}

Means and standard deviations for the variables were computed and correlation analysis was carried out to analyze relationship among four variables. Results of the Pearson Correlation Analysis (2-tailed) displayed statistically significant and positive relationship between ethical sensitivity and academic performance $(r=0.250 ; 0.006)$; self-esteem and ethical sensitivity $(r=0.209 ; 0.18)$ and statistically significant and negative relationship between cynicism and self-esteem $(r=-0.239 ; p=0.008)$. The data were also evaluated using 1tailed Pearson correlation analysis. Results of the 1-tailed Pearson correlation analysis showed that self-esteem has statistically significant and positive impact on the academic performance $(r=0.177 ; 0.039)$ at the level of 0.05 . Means, standard deviations and correlations among variables are shown in Table 2. 
Table 2. Mean, standard deviation, correlation coefficients

\begin{tabular}{|l|l|c|c|c|c|c|c|}
\hline & Variables & Means & $\begin{array}{c}\text { Standard } \\
\text { Deviation }\end{array}$ & $\mathbf{1}$ & $\mathbf{2}$ & $\mathbf{3}$ & $\mathbf{4}$ \\
\hline $\mathbf{1}$ & Academic Performance & 75.5050 & 11.63535 & 1.00 & & & \\
\hline $\mathbf{2}$ & Ethical Sensitivity & 3.3238 & 1.13263 & $0.250\left(^{*}\right)$ & 1.00 & & \\
\hline $\mathbf{3}$ & Self-Esteem & 3.9140 & 0.78226 & 0.177 & $0.209\left(^{*}\right)$ & 1.00 & \\
\hline $\mathbf{4}$ & Cynicism & 3.2200 & 1.01196 & 0.128 & $-0.239\left(^{*}\right)$ & 0.121 & 1.00 \\
\hline
\end{tabular}

Note: Correlation is significant at the 0.05 level (2-tailed).

\subsection{Test of the Hypothesis}

The aim of this study is to examine the impact of ethical sensitivity, self-esteem and cynicism on the academic performance and the relationships among these variables. For these purpose two regression models were analyzed. In the first and second regression models, the effects of ethical sensitivity and self-esteem on academic performance were investigated. In the second regression model, the effects of self-esteem and cynicism on ethical sensitivity were analyzed.

The first regression model exploring the impact of ethical sensitivity on academic performance is statistically significant $\left(F=6.511 ; R^{2}=0.053 ; p=0.012\right)$. Ethical sensitivity has statistically significant and positive impact on the academic performance of business students in financial accounting course $(\beta=0.250 ; p=0.012)$. These results support Hypotheses 1 . The second regression model investigates the relationship between self-esteem and academic performance. Results indicate that the model is statistically significant $\left(F=3.163 ; R^{2}=0.021\right.$; $p=0.078)$. Self-esteem positively affects the academic performance $(\beta=0.177 ; p=0.078)$ at the level of 0.10 . These results support Hypotheses 2. Table 3 displays the results of the first regression analyses.

Table 3. Results of the regression analyses

\begin{tabular}{lcccccc} 
Independent Variable & Beta & $\mathrm{t}$ & $\mathrm{F}$ & $\mathrm{R}^{2}$ & Adjusted $\mathrm{R}^{2}$ & Sig. \\
\hline Ethical Sensitivity & 0.250 & 2.552 & 6.511 & 0.062 & 0.053 & 0.012 \\
\hline Self-Esteem & 0,177 & 1.779 & 3.163 & 0.031 & 0.021 & 0.078 \\
\hline
\end{tabular}

Note: Dependent Variable: Academic Performance

The third regression model investigating the impact of self-esteem and cynicism on ethical sensitivity is statistically significant $\left(F=6.290\right.$; Adjusted $\left.R^{2}=0.097 ; p=0.003\right)$. Selfesteem has statistically significant and positive impact on ethical sensitivity of business students $(\beta=0.242 ; p=0.014)$. In contrast, cynicism has statistically significant but negative impact on the ethical sensitivity as it is purposed $(\beta=-0.269 ; p=0.006)$. These results support Hypotheses 3 and Hypothesis 5. Table 4 displays the results of the third regression analyses.

Table 4. Results of the regression analyses

\begin{tabular}{lcccccc}
\hline Independent Variable & Beta & $\mathrm{t}$ & $\mathrm{F}$ & $\mathrm{R}^{2}$ & $\begin{array}{c}\text { Adjusted } \\
\mathrm{R}^{2}\end{array}$ & Sig. \\
\hline Self-Esteem & 0.242 & 2.510 & & & & 0.014 \\
Cynicism & -0.269 & -2.792 & 6.290 & 0.115 & 0.097 & 0.006 \\
\hline
\end{tabular}

Note: Dependent Variable: Ethical Sensitivity 
Hypothesis 4 purposes that ethical sensitivity has mediation effect between self-esteem and academic performance. On the basis of Baron and Kenny's (1986) explanations about mediator variable analysis, mediation analysis was conducted. Firstly, the effect of self-esteem on ethical sensitivity was analyzed. Secondly, the impact of ethical sensitivity and self-esteem on academic performance will be examined separately. At third stage the joint effect of selfesteem and ethical sensitivity on academic performance were examined. The results of the regression analysis were presented in Table 5 . The results displayed that regression models are statistically significant $(F: 4.477, \beta=0.209, p=0.037 ; F: 6.511, \beta=0.250, p=0.12 ; F: 4.135$, $\beta=0.130, \beta=0.222, p=0.019$ ) at the level of 0.05 . The regression model investigating the relationship between self esteem and academic performance is not significant at the level of 0.05 . However it can be accepted as a statistically significant at the level of 0.10 (F: 3.163; $\beta=0.177 ; p=0.078$ ). At the third stage, as it is expected, it is seen that significant relationship between self-esteem and academic performance at second stage is not significant at third stage $(p=0.198)$ in accordance with the explanations of Baron and Kenny (1986). This result indicates that ethical sensitivity has mediation effect on the relationship between self-esteem and academic performance. So, the results of mediation analysis support the Hypothesis 4 .

Table 5. Results of the regression analyses

\begin{tabular}{|c|c|c|c|c|c|c|c|c|}
\hline Step & \multicolumn{2}{|c|}{ Independent Variable } & $\beta$ & $t$ & $\mathbf{F}$ & R2 & $\begin{array}{c}\text { Adjusted } \\
\text { R2 }\end{array}$ & Sig. \\
\hline 1 & \multicolumn{2}{|c|}{ Self-Esteem-Ethical Sensitivity } & 0.209 & 2.116 & 4.477 & 0.044 & 0.034 & 0.037 \\
\hline $2 a$ & \multicolumn{2}{|c|}{ Self-Esteem-Academic Performance } & 0.177 & 1.779 & 3.163 & 0.031 & 0.021 & 0.078 \\
\hline $2 b$ & \multicolumn{2}{|c|}{ Ethical Sensitivity-Academic Performance } & 0.250 & 2.552 & 6.511 & 0.062 & 0.053 & 0.012 \\
\hline \multirow{2}{*}{3} & \multirow{2}{*}{$\begin{array}{l}\text { Self-Esteem } \\
\text { Ethical Sensitivity }\end{array}$} & \multirow{2}{*}{$\begin{array}{ll}- & \text { Academic } \\
- & \text { Performance }\end{array}$} & 0.130 & 1.308 & \multirow{2}{*}{4.135} & \multirow{2}{*}{0.079} & \multirow{2}{*}{0.060} & 0.194 \\
\hline & & & 0.222 & 2.231 & & & & 0.028 \\
\hline
\end{tabular}

\section{Conclusion}

In this study, the effects of self-esteem, cynicism and ethical sensitivity on academic performance of undergraduate business students in financial accounting course were investigated. The data obtained from undergraduate business students of one public university in Turkey via questionnaire. The data was examined with the help of factor, reliability and regression analyses. Because the scales of the current study were adapted from previous studies in literature, their validities and reliabilities were proven by different studies. The results of the present study also confirmed the reliability and validity of scales.

The results show that ethical sensitivity and self-esteem have positive effect on academic performance of business students in financial accounting course. It means that increase in ethical sensitivity and self-esteem of students will also increase the academic performance of them. It confirms the results of Giovazolias et al. (2008), Akinleke (2012), and Arshad et al. (2015). It shows the importance of ethic education at universities in a different perspective. If students have more self-esteem and more ethical sensitivity, they will be more successful in financial accounting courses at the universities. These results provide a starting point for accounting academicians to examine the role of ethical sensitivity in academic success of business students in accounting course.

It is also seen that if the students have more self-esteem, they also have more ethical sensitivity. Ethical sensitivity also plays the mediation role between self-esteem and academic performance. Another finding of the study is that cynicism negatively affects the ethical 
sensitivity of students. In other words, cynical students have less ethical sensitivity in comparison with students which are not cynical. These findings confirm Sierles et al. (1980) and Ameen et al. (1996).

As all researches, this study also has some limitations. Firstly, the sample of the study is business students of one public university. Because of the differences between public and private university education, the generalization of the study to private universities cannot be meaningful. Because of the time constraint, the effects of limited variables on academic performance were analyzed. Investigating the effects of other variables influencing academic performance of students was left to the future researches.

\section{References}

Adkins, N. and Radtke, R.R., 2004. Students' and faculty members' perceptions of the importance of business ethics and accounting ethics education: Is there an expectations gap? Journal of Business Ethics, 51(3), pp.279-300. http://dx.doi.org/10.1023/B:BUSI.0000032700.07607.02

Afifah, U., Sari, R.N., Anugerah, R., and Sanusi, Z.M., 2015. The effect of role conflict, selfefficacy, professional ethical sensitivity on auditor performance with emotional quotient as moderating variable. Procedia Economics and Finance, 31, pp.206-212. http://dx.doi.org/10.1016/S2212-5671(15)01222-8

Akinleke, O.W., 2012. An investigation of the relationship between test anxiety, self esteem and academic performance among polytechnic students in Nigeria. International Journal of Computer Applications, 51(1), pp.47-50.

Ameen, E.C., Guffey, D.M., and McMillan, J.J., 1996. Gender differences in determining the ethical sensitivity of future accounting professionals. Journal of Business ethics, 15(5), pp.591-597. http://dx.doi.org/10.1007/BF00381934

Arshad, M., Zaidi, S.M.I.H., and Mahmood, K., 2015. Self-esteem \& academic performance among university students. Journal of Education and Practice, 6(1), pp.156-162.

Babbie, E., 1989. The practice of social research. 5th ed. California: Wadsworth Publishing.

Babbie, E., 1990. Survey research methods. 2nd ed. Belmont, CA: Wadsworth.

Baron, R. and Kenny, D., 1986. The moderator-mediator variable distinction in social psychological research. Journal of Personality and social psychology, 51(6), pp.11731182. http://dx.doi.org/10.1037/0022-3514.51.6.1173

Baumeister, R.F., Campbell, J.D., Krueger, J.I., and Vohs, K.D., 2003. Does high self-esteem cause better performance, interpersonal success, happiness, or healthier lifestyles? Psychological Science in the Public Interest, 4(1), pp.1-44. http://dx.doi.org/10.1111/1529-1006.01431

Chan, S. Y. and Leung, P., 2006. The effects of accounting students' ethical reasoning and personal factors on their ethical sensitivity. Managerial Auditing Journal, 21(4), pp.436457. http://dx.doi.org/10.1108/02686900610661432

Cohen, J.R. and Pant, L.W., 1989. Accounting educators' perceptions of ethics in the curriculum. Issues in Accounting Education, 4(1), pp.70-81.

Cohn, E., 1972. Students' characteristics and performance in economic statistics. The Journal of Economic Education, 3(2), pp.106-111. http://dx.doi.org/10.1080/00220485.1972.10845350

Cole, B.C. and Smith, D.L., 1995. Effects of ethics instruction on the ethical perceptions of college business students. Journal of Education for Business, 70(6), pp.351-356. http://dx.doi.org/10.1080/08832323.1995.10117777

Crocker, J. and Luhtanen, R.K., 2003. Level of self-esteem and contingencies of self-worth: Unique effects on academic, social, and financial problems in college students. Personality and Social Psychology Bulletin, 29(6), pp.701-712. http://dx.doi.org/10.1177/0146167203029006003 
Dellaportas, S., Jackling, B., Leung, P., and Cooper, B.J., 2011. Developing an ethics education framework for accounting. Journal of Business Ethics Education, 8(1), pp.63-82.

Duizend, J. and McCann, G.K., 1998. Do collegiate business students show a propensity to engage in illegal business practices? Journal of Business Ethics, 17(3), pp.229-238. http://dx.doi.org/10.1023/A:1017945925104

Fischer, M. and Rosenzweig, K., 1995. Attitudes of students and accounting practitioners concerning the ethical acceptability of earnings management. Journal of Business Ethics, 14(6), pp.433-444. http://dx.doi.org/10.1007/BF00872085

Gautschi, F.H. and Jones, T.M., 1998. Enhancing the ability of business students to recognize ethical issues: An empirical assessment of the effectiveness of a course in business ethics. Journal of Business Ethics, 17(2), pp.205-216. http://dx.doi.org/10.1023/A:1005740505208

Geary, W.T. and Sims, R.R., 1994. Can ethics be learned? Accounting Education, 3(1), pp.318. http://dx.doi.org/10.1080/09639289400000002

Giovazolias, T., Karademas, E., and Kalantzi-Azizi, A., 2008. Crossing internal and external borders. Practices for an effective psychological counseling in the European Higher Education. In: T. Giovazolias, K. Maniorou, E. Papachristodoulou, and E. Mitsopoulou, ed. 2008. The relationship between dysfunctional eating attitudes, alexithymia and family bonds in Greek students. Athens: Ellinika Grammata and FEDORA-PSYCHE.

Guney, Y., 2009,. Exogenous and endogenous factors influencing students' performance in undergraduate accounting modules. Accounting Education, 18(1), pp.51-73. http://dx.doi.org/10.1080/09639280701740142

Hartnett, N., Romcke, J., and Yap, C., 2004. Student performance in tertiary-level accounting: an international student focus. Accounting \& Finance, 44(2), pp.163-185. http://dx.doi.org/10.1111/i.1467-629X.2004.00104.x

Hunt, S.D. and Vitell, S.J., 2006. The general theory of marketing ethics: A revision and three questions. Journal of Macromarketing, 26(2), pp.143-153. http://dx.doi.org/10.1177/0276146706290923

Jussim, L., Coleman, L., and Nassau, S., 1987. The influence of self-esteem on perceptions of performance and feedback. Social Psychology Quarterly, 50(1), pp.95-99. http://dx.doi.org/10.2307/2786894

Kerr, D.S. and Smith, L.M., 1995. Importance of and approaches to incorporating ethics into the accounting classroom. Journal of Business Ethics, 14(12), pp.987-995. http://dx.doi.org/10.1007/BF00872114

Kopelman, L., 1983. Cynicism among medical students. Jama, 250(15), pp.2006-2010. http://dx.doi.org/10.1001/jama.1983.03340150048025

Landis, B.D., Altman, J.D., and Cavin, J.D., 2007. Underpinnings of academic success: Effective study skills use as a function of academic locus of control and self-efficacy. Psi Chi Journal of Undergraduate Research, 12(3), pp.126-130.

Loeb, S.E., 1988. Teaching students accounting ethics: Some crucial issues. Issues in Accounting Education, 3(2), pp.316-329.

Malhotra, N.K., 1993. Marketing research: An applied orientation. Englewood Cliffs, NJ: Prentice-Hall.

Mitchell, V.W., 1994. How to identify psychographic segments: Part 1. Marketing Intelligence and Planning, 12(7), pp.4-10. http://dx.doi.org/10.1108/EUM0000000003905

Nakip, M., 2003. Pazarlama araştırmaları: teknikler ve (SPSS destekli) uygulamalar (Marketing Research: Techniques and (SPSS Supported) Applications). Ankara: Seçkin Yayıncılık.

Nunnally, J.C., 1978. Psychometric theory. New York: McGraw-Hill.

Ponemon, L.A., 1993. Can ethics be taught in accounting? Journal of Accounting Education, 11(2), pp.185-209. http://dx.doi.org/10.1016/0748-5751(93)90002-Z

Rankin, M., Silvester, M., Vallely, M., and Wyatt, A., 2003. An analysis of the implications of diversity for students' first level accounting performance. Accounting \& Finance, 43(3), pp.365-393. http://dx.doi.org/10.1111/j.1467-629x.2003.00096.x 
Rosenberg, M., 1963. Parental interest and children's self-conceptions. Sociometry, 26(1), pp.35-49. http://dx.doi.org/10.2307/2785723

Sierles, F., Hendrickx I., and Circel, S., 1980. Cheating in Medical School. Journal of Medical Education, 55(2), pp.124-125. http://dx.doi.org/10.1097/00001888-198002000-00006

Simga-Mugan, C., Daly, B.A., Onkal, D., and Kavut, L., 2005. The influence of nationality and gender on ethical sensitivity: An application of the issue-contingent model. Journal of Business ethics, 57(2), pp.139-159. http://dx.doi.org/10.1007/s10551-004-4601-z

Sparks, J.R. and Hunt, S.D., 1998. Marketing researcher ethical sensitivity: Conceptualization, measurement, and exploratory investigation. The Journal of Marketing, 62(2), pp.92109. http://dx.doi.org/10.2307/1252163

Yilmaz, E., 2011. Benlik saygısı, kontrol odağı ve öğrenme stillerinin akademik başarıya etkisi: Üniversite öğrencileri üzerine bir araştırma [The effect of self-esteem, locus of control and learning styles on academic success: A study on university students]. Master's Thesis. Turkish Military Academy. 